\title{
Growth and reproduction investment of the young of the year of the squat lobster Munida gregaria (Crustacea: Anomura) in the Patagonian coast
}

\author{
Martin Varisco, Julio H. Vinuesa \\ Centro de Investigación y Transferencia Chubut, Universidad Nacional de la Patagonia San Juan Bosco, Consejo Nacional \\ de Investigaciones Científicas y Técnicas, Ruta provincial 1, km 4, oficina 460, Comodoro Rivadavia, Chubut, Argentina, \\ CP 9000. E-mail: martinvarisco@ hotmail.com
}

\begin{abstract}
Summary: The growth and reproduction investment of the young of the year $(0+)$ of the squat lobster Munida gregaria in San Jorge Gulf, Argentina, were analysed. Moult cycle and size frequency distribution were studied in monthly field samples. Experiments to determine moult increments and intermoult duration were conducted. Sexual maturity, fecundity and reproductive output were analysed in field samples. In addition, maturity experiments in laboratory cultures were conducted. After settlement (November), juveniles showed fast growth until winter (July) and growth restarted in September-October. At the beginning of the mating period (early June), males 0+ exhibited mature gonads, whereas females 0+ only showed previtellogenic oocytes. Experimental data showed that females with developed gonads had smaller-size increments in the previous moult. Fecundity and reproductive output were significantly lower in females $0+$ than in older females. The early life history of M. gregaria in San Jorge Gulf differs from that of southern populations as those of Beagle Channel and Strait of Magellan due to faster growth and early reproductive investment. Our results suggest that females $0+$ of $M$. gregaria have two investment strategies: early maturity with low fecundity and delayed maturity with higher future fecundity.
\end{abstract}

Keywords: resource allocation; growth; moult; maturity; fecundity; squat lobsters; Munida gregaria, Patagonia.

Crecimiento e inversión reproductiva de juveniles de la langostilla Munida gregaria (Crustacea: Anomura) en la costa Patagónica

Resumen: Se estudió el crecimiento y la inversión reproductiva de juveniles tempranos (0+) de la langostilla Munida gregaria en el Golfo San Jorge, Argentina. El ciclo de muda y la distribución de tallas fueron analizados mensualmente en muestras de campo. Se realizaron experiencias de laboratorio para determinar el incremento por muda y la duración de la intermuda. La madurez sexual, fecundidad y el esfuerzo reproductivo fueron analizados en muestras de campo. Además, la madurez gonadal fue evaluada en cultivos de laboratorio. Luego del asentamiento (noviembre), los juveniles 0+ muestran un periodo de crecimiento rápido que se prolonga hasta julio, cuando la actividad de muda decrece. La actividad de muda se reinicia en septiembre-octubre. Al comienzo del periodo reproductivo (junio), los machos 0+ presentan gónadas maduras mientras que las hembras muestran oocitos previtelogénicos. Las hembras presentan oocitos vitelogénicos en los meses posteriores próximos al final del periodo de cópula. Las experiencias de laboratorio muestran que las hembras $0+$ que maduran sus gónadas tienen incrementos por muda inferiores en la muda previa, respecto de aquellas hembras que no alcanzan la madurez. La fecundidad y el esfuerzo reproductivo fueron significativamente menores en hembras 0+ que en hembras de cohortes más avanzadas. La historia de vida temprana de M. gregaria en el Golfo San Jorge difiere de la observada en poblaciones más australes, como el Canal Beagle y el Estrecho de Magallanes, debido al rápido crecimiento y a la inversión reproductiva más temprana. Nuestros resultados sugieren que las hembras 0+ de $M$. gregaria tienen dos estrategias de inversión: madurez temprana con baja fecundidad o madurez retrasada con una mayor fecundidad en el futuro.

Palabras clave: crecimiento; muda; madurez sexual; fecundidad; langostillas; Munida gregaria; Patagonia.

Citation/Como citar este artículo: Varisco M., Vinuesa J.H. 2015. Growth and reproduction investment of the young of the year of the squat lobster Munida gregaria (Crustacea: Anomura) in the Patagonian coast. Sci. Mar. 79(3): 345-353. doi: http://dx.doi.org/10.3989/scimar.04201.03A

Editor: C. Froglia.

Received: January 7, 2015. Accepted: June 3, 2015. Published: July 6, 2015.

Copyright: () 2015 CSIC. This is an open-access article distributed under the Creative Commons Attribution-Non Commercial Lisence (by-nc) Spain 3.0. 


\section{INTRODUCTION}

Growth and reproduction are antagonist processes that play a central role in the life history of species. The different ways in which resources are allocated to growth and reproduction form the basis of the different life-history strategies in marine invertebrates (Ramírez Llodra 2002). Resource partitioning has a strong influence on life-history traits such as age at maturity, fecundity and growth rates (Stearns 1992, Heino and Kaitala 1999). Crustacean decapods exhibit a great diversity of growth and reproduction patterns, but constrained by two basic growth models: determinate and indeterminate (Hartnoll 1985). In decapod species with determinate growth (e.g. Majoidea), resource allocation to growth and reproduction is temporarily separated, whereas decapod species with indeterminate growth experience a life-history trade-off in resource allocation between reproduction and growth throughout their lives. In both growth models, size and age at maturity play a pivotal role in the life cycle of species because selection pressures change drastically. Age at maturity is an allocation decision that results from the balance between costs and benefits of starting reproduction investment at this age (Stearns 1992, Ramírez Llodra 2002).

Squat lobsters (as other Anomura) have indeterminate growth. Thus, they allocate resources between growth and reproduction after reaching sexual maturity. Traits related to moult cycle, growth and reproductive periods of squat lobsters have been analysed in Pleuroncodes monodon, Cervimunida johni, Munida intermedia and Munida rutllanti among others (Roa and Bahamonde 1993, Wolff and Aroca 1995, Gramitto and Froglia 1998, Petrić et al. 2010, Espinoza-Fuenzalida et al. 2012, Thiel et al. 2012). In particular, the growth traits of Munida gregaria have been analysed in the Beagle Channel (Tapella 2002), the Strait of Magellan (Rodríguez and Bahamonde 1986) and near the Islas Malvinas (Falkland Islands) (Rayner 1935). Reproductive aspects (size at maturity, fecundity, egg size) of $M$. gregaria have also been studied in some locations of the southwestern Atlantic Ocean (Tapella et al. 2002, Vinuesa 2007, Dellatorre and González-Pisani 2010). In the San Jorge Gulf, Patagonia Argentina, the breeding period of this species starts in early June and continues to mid-December. In this period, females can have two spawnings. Females reached physiological maturity at a carapace length (CL) of between 9 and $12 \mathrm{~mm}$ males at a CL of between 6 and $8 \mathrm{~mm}$ (Vinuesa 2007).

The aim of this study was to analyse the growth and reproduction investment of the young of the year $(0+)$ of the squat lobster Munida gregaria in San Jorge Gulf. We hypothesized that a) Munida gregaria reaches maturity in the first year after settlement, b) the young of the year can reproduce only at the end of the breeding period, and c) the reproduction investment of females $(0+)$ is significantly lower than that of older females.

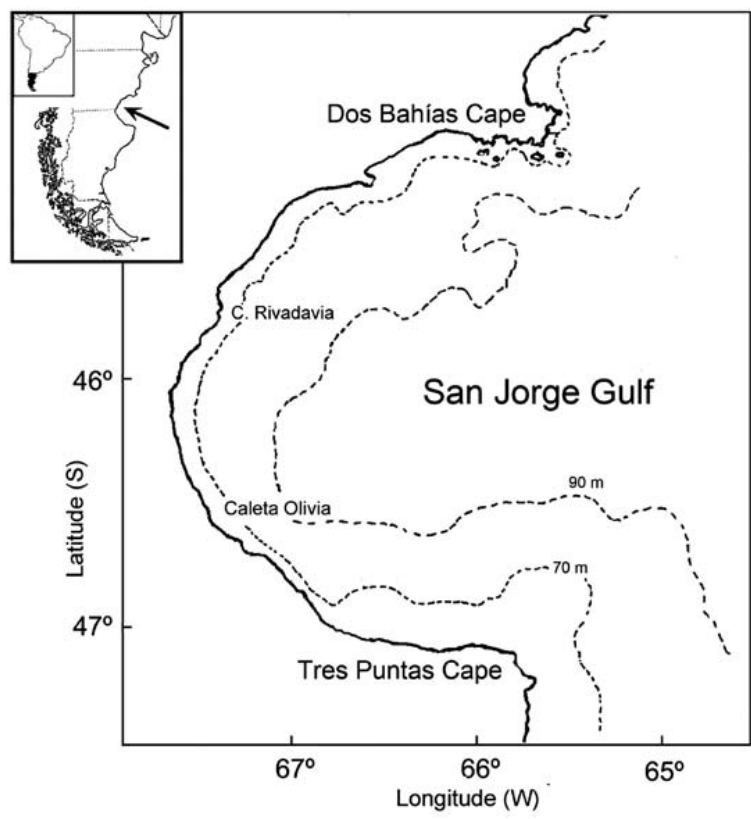

Fig. 1. - San Jorge Gulf, southwestern Atlantic Ocean.

\section{MATERIALS AND METHODS}

\section{Study area}

The study was performed in the San Jorge Gulf, Argentina (Fig. 1). The gulf extends from Cape Dos Bahías (445 $5^{\prime} 26^{\prime}$ 'S $\left.65^{\circ} 33^{\prime} 12^{\prime \prime} \mathrm{W}\right)$ in the north to Cape Tres Puntas (47 $\left.06^{\prime} 00^{\prime \prime} \mathrm{S} 65^{\circ} 53^{\prime} 00^{\prime \prime} \mathrm{W}\right)$ in the south. Its maximum depth is approximately $100 \mathrm{~m}$. The water in the San Jorge Gulf is a mixture of sub-Antarctic water from the Cape Horn Current and low-salinity water of the Magellan plume. The latter, which originated from the discharge from the Strait of Magellan, extends along the inner shelf of southern Patagonia (Palma et al. 2008). In coastal areas, the minimum surface temperature is $7.6^{\circ} \mathrm{C}$ and the maximum is $17.3^{\circ} \mathrm{C}$. Salinity ranges between 33.1 and 34.2 (Vinuesa et al. 2011).

\section{Growth}

\section{Size of the first juvenile}

To determine the size of the first juvenile, plankton samples were collected from the coastal area near Comodoro Rivadavia (Chubut, Argentina) in October-November 2008. Decapodites were randomly selected and transferred into individual bowls with $150 \mathrm{ml}$ of seawater at $8^{\circ} \mathrm{C}$. Three times a week, seawater was changed, and recently hatched Artemia nauplii were supplied. When the decapodites moulted, the CL of juveniles was measured from the posterior edge of the orbit to the posterior mid-dorsal edge of the carapace, using a stereoscopic microscope with a graduated ocular $( \pm 0.01 \mathrm{~mm})$. Juveniles were kept in the laboratory until the next moult to estimate intermoult duration and size of the second juvenile instar. Seawater was changed once a week and juveniles were fed three times a week with the isopods Exosphaeroma sp. and commercial fish food. 


\section{Moult cycle}

Squat lobsters were sampled monthly from boats using a bottom net with a $2-\mathrm{m}$ net mouth and a $10-\mathrm{mm}$ mesh size. Samplings were carried out between June 2008 and December 2009 at a depth ranging between 30 and $97 \mathrm{~m}$ in areas adjacent to the city of Comodoro Rivadavia. In the laboratory, the CL was measured using a digital caliper $( \pm 0.01 \mathrm{~mm})$ or using a stereoscopic microscope with a graduated ocular $( \pm 0.01 \mathrm{~mm})$ for smaller juveniles. Moult activity was analysed monthly in randomly selected field subsamples of ten males and ten females. Moult stages were identified, observing the changes in the distal edge of the exopodite of the second maxilliped according with the criteria used by Tapella (2002). The distal edge of the exopodite was removed and observed under a microscope (100x).

\section{Moult increment}

Specimens that were presumed to be in premoult according to carapace colour and hardness were placed in individual plastic mesh cages in aquaria with variable conditions fixed to environmental conditions of temperature, salinity and light:dark duration. Food (isopods Exosphaeroma sp. and commercial fish food) was supplied three times a week, and seawater was changed once a week. Premoult and postmoult CL were recorded to calculate moult increments

$$
\mathrm{MI}=\mathrm{CL}_{\mathrm{pos}}-\mathrm{CL}_{\text {pre }}
$$

The relative increment was also calculated as

$$
\mathrm{RI}=\left(\mathrm{CL}_{\text {pos }}-\mathrm{CL}_{\text {pre }}\right) / \mathrm{CL}_{\text {pre }} \text {. }
$$

To minimize a possible effect of culture, only squat lobsters that moulted in the first 15 days after the sampling were considered. However, after the moult, specimens were maintained in the laboratory to estimate intermoult duration.

A regression was made between $\mathrm{CL}_{\text {pre }}$ and growth indicators $\left(\mathrm{CL}_{\mathrm{pos}}, \mathrm{MI}\right.$ and $\left.\mathrm{RI}\right)$. Analysis of covariance (ANCOVA) was used to determine whether regression equations differed between sexes. Homogeneity of slopes was previously tested. Comparison was considered significant when $\mathrm{P}<0.05$.

\section{Size frequency distribution}

Length-frequency histograms were built using CL data. Bhattacharya's method was applied to length-frequency analysis, using FiSAT II (Gayanilo et al. 2005).

\section{Reproduction investment}

\section{Gonadal development}

The gonadal development of the young of the year was analysed in field samples from June to October and laboratory assays. Based on size-frequency distribution and available data about the reproduction of $M$. gregaria
(Vinuesa 2007), we considered that ovigerous females smaller than $13 \mathrm{~mm}$ CL were mainly specimens $0+$. Additional samplings in the reproductive period were carried out in 2010 and used to analyse gonadal development and fecundity. After morphometric and sex data were recorded, subsample specimens $(n=30)$ were dissected and the gonads were removed. The presence of spermatophores in the deferent duct and of vitellogenic oocytes was considered as an indicator of gonadal maturity in males and females, respectively. A smear of the deferent ducts was observed under a microscope at 400x magnification. In females, the diameter of 40 oocytes was measured using a stereoscopic microscope with an ocular micrometer to the nearest $0.01 \mathrm{~mm}$. Oocytes were classified as previtellogenic and vitellogenic according to earlier works (Tapella et al. 2002, Vinuesa 2007). The presence of eggs in females was also recorded.

The analysis of field samples did not preclude the possibility that the smallest specimens of the previous cohort could be involved in the analysis, particularly at the end of the first year, so laboratory experiments were performed. In 2009, young of the year $(n=100)$ of both sexes with CL ranging between 7.91 and 9.42 $\mathrm{mm}$ were placed in individual plastic mesh cages in aquaria. The experiments started in May and continued until October according to the breeding period reported in an earlier work (Vinuesa 2007). Ten males and ten females were sampled monthly and then measured and dissected. Gonadal development and moult stage were evaluated according to the methods and criteria mentioned above. Moult increments were recorded during the experiments to evaluate differences in growth of mature and immature individuals. Analysis of variance (ANOVA) was performed to compare moult increments in the two groups. Homogeneity of variance and normality assumptions of ANOVA were previously tested. Comparison was considered significant when $\mathrm{P}<0.05$.

\section{Fecundity and reproductive output}

Realized fecundity (Ramírez Llodra 2002) and reproductive output (RO) (Hines 1982) were analysed in females 0+. Squat lobsters were measured as mentioned above and the egg masses were detached from pleopods. Fecundity was estimated using gravimetric procedures described by Vinuesa (2007). Egg masses were oven-dried at $60^{\circ} \mathrm{C}$ for $48 \mathrm{~h}$ and then weighed with an analytical balance $(0.0001 \mathrm{~g})$. A fraction of eggs (no less than 300) was used.

The weights of egg dry masses and squat lobster dry mass were used to estimate RO. Thirty squat lobsters of each year were dried and weighed according to the procedures mentioned above. These procedures were also used in older females to compare fecundity and $\mathrm{RO}$ in both groups.

Piecewise regression variance was used to evaluate differences in fecundity between females $0+$ and older females. ANOVA was used to evaluate differences in RO between two groups of females. Homogeneity of variance and normality were previously tested. Comparison was considered significant when $\mathrm{P}<0.05$. 


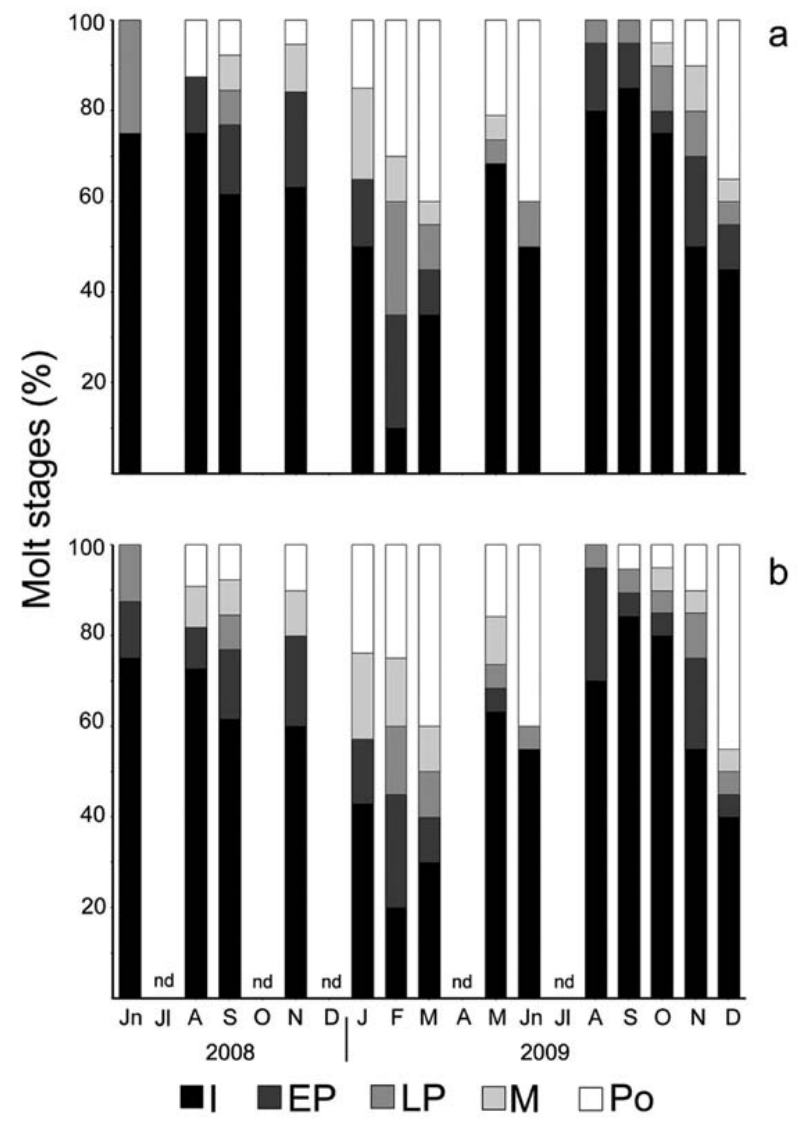

Fig. 2. - Moult stages in females (a) and males (b) of young of the year of Munida gregaria in San Jorge Gulf. I, intermoult; EP, early premoult; LP, late premoult; M, moult; Po, postmoult.

\section{RESULTS}

\section{Growth}

\section{Size of the first juvenile}

The size of postlarvae ranged between 1.98 and $2.69 \mathrm{~mm}(2.38 \pm 0.15 \mathrm{~mm}$ CL). First juvenile CL varied between 2.07 and $3.26 \mathrm{~mm}(2.45 \pm 0.17 \mathrm{~mm} \mathrm{CL})$. Most postlarvae moult to juveniles in mid-November. Juveniles moulted again 15-20 days after the settlement. The size of the second juvenile instar ranged between 2.56 and 4.05 (3.45 $\pm 0.48 \mathrm{~mm} \mathrm{CL})$.

\section{Moult cycle}

Moult activity was higher during summer and early autumn, while at the end of winter (August-September) most squat lobsters were in intermoult. Moulting activity started again in spring. The moult cycle was similar between females and males (Fig. 2).

\section{Moult increment and intermoult duration}

Growth indicators $\left(\mathrm{CL}_{\text {pos }}\right.$, $\mathrm{MI}$ and $\left.\mathrm{RI}\right)$ were related to $\mathrm{CL}_{\text {pre }}$ and were similar in males and females (Table 1). In agreement with Hiatt's criteria (Kurata 1962), the young of the year of both sexes showed positive
Table 1. - Results of the regression analysis for $\mathrm{CL}_{\mathrm{pre}}$ and growth indicators $\mathrm{CL}_{\text {pos }}$, moult increments (MI) and relative increments (RI). Analysis of covariance to test differences between sexes. N, number of individuals; $\mathrm{R}^{2}$, determination coefficient; F, statistic F; $\mathrm{P}$, probability; Significance level $(\mathrm{P}<0.05)$

\begin{tabular}{llcccc}
\hline & \multicolumn{1}{c}{ Equation } & $\mathrm{N}$ & $\mathrm{R}^{2}$ & $\mathrm{~F}$ & $\mathrm{P}$ \\
\hline Post moult & & & & & \\
Males & $\mathrm{CL}_{\text {pos }}=1.13 \mathrm{CL}_{\text {pre }}+0.10$ & 24 & 0.99 & 3478 & $<0.01$ \\
Females & $\mathrm{CL}_{\text {pos }}=1.10 \mathrm{CL}_{\text {pre }}+0.31$ & 25 & 0.99 & 4042 & $<0.01$ \\
Slope & $\mathrm{H}_{\mathrm{o}} \mathrm{b}_{\text {males }}=\mathrm{b}_{\text {females }}$ & & & 0.67 & 0.41 \\
Intercept & $\mathrm{H}_{\mathrm{o}} \mathrm{a}_{\text {males }}=\mathrm{a}_{\text {females }}$ & & & 0.13 & 0.71 \\
MI & & & & & \\
Males & $\mathrm{MI}=0.13 \mathrm{CL}_{\text {pre }}+0.10$ & 24 & 0.68 & 50.9 & $<0.01$ \\
Females & $\mathrm{MI}=0.10 \mathrm{CL}_{\text {pre }}+0.31$ & 25 & 0.62 & 38.7 & $<0.01$ \\
Slope & $\mathrm{H}_{\mathrm{o}} \mathrm{b}_{\text {males }}=\mathrm{b}_{\text {females }}$ & & & 0.67 & 0.41 \\
Intercept & $\mathrm{H}_{\mathrm{o}} \mathrm{a}_{\text {males }}=\mathrm{a}_{\text {females }}$ & & & 0.13 & 0.71 \\
RI & & & & & \\
Males & $\mathrm{RI}=-0.50 \mathrm{CL}_{\text {pre }}+19.8$ & 24 & 0.20 & 5.50 & 0.02 \\
Females & $\mathrm{RI}=-0.75 \mathrm{CL}_{\text {pre }}+21.3$ & 25 & 0.23 & 38.7 & 0.01 \\
Slope & $\mathrm{H}_{\mathrm{o}} \mathrm{b}_{\text {males }}=\mathrm{b}_{\text {females }}$ & & & 0.32 & 0.57 \\
Intercept & $\mathrm{H}_{\mathrm{o}} \mathrm{a}_{\text {males }}=\mathrm{a}_{\text {females }}$ & & & 0.07 & 0.93 \\
\hline
\end{tabular}

allometric growth $(b>1)$. Moult increment was higher in larger-size individuals $(0+)$. However, the relative increment was higher in small juveniles and negatively related to $\mathrm{CL}_{\text {pre }}$ (Fig. 3). Intermoult duration was also negatively related to $\mathrm{CL}\left(\mathrm{R}^{2}=0.76 ; \mathrm{F}_{(1,49)}=158.6\right.$; $\mathrm{p}<0.01)$. In smaller-size squat lobsters $(\approx 4 \mathrm{~mm} C L)$ intermoult lasted approximately 15 days, whereas in larger-size individuals $(\approx 11 \mathrm{~mm} \mathrm{CL})$ intermoult lasted 45-57 days (Fig. 4).

\section{Size frequency distribution}

Decapodite moults suggest that the first juveniles settle in November. In field samples, early juveniles were observed in January. In agreement with the size of first juvenile and moult increment observed, the smallest juveniles found in field samplings would correspond to third crab instar. After settlement, juveniles showed fast growth until winter. Growth restarted in September-October (Fig. 5). Seven size classes were identified from January to October. The size frequency distribution was similar in males and females. Differences in size between males $(12.56 \pm 0.44 \mathrm{~mm} \mathrm{CL})$ and females $(11.90 \pm 0.76 \mathrm{~mm} \mathrm{CL})$ appeared at the end of the first year after the settlement (Table 2).

\section{Reproduction}

\section{Gonadal development}

Males 0+ showed spermatophores in the deferent duct during all the reproductive periods from June to October. At the beginning of the breeding period, nearly $70 \%$ of males had mature gonads. In August 2008, all males 0+ analysed had spermatophores in the deferent duct, while the maximum proportion of mature males was $90 \%$ in 2009 and $86.6 \%$ in 2010 (Fig. 6). In the laboratory experiments, only $40 \%$ of males had mature gonads in June. As was observed in the 2008 field samples, in the laboratory experiments, all males were mature in August (Fig. 7a). During the experiments, males moulted at the end of June and again at the end of September. 
Males
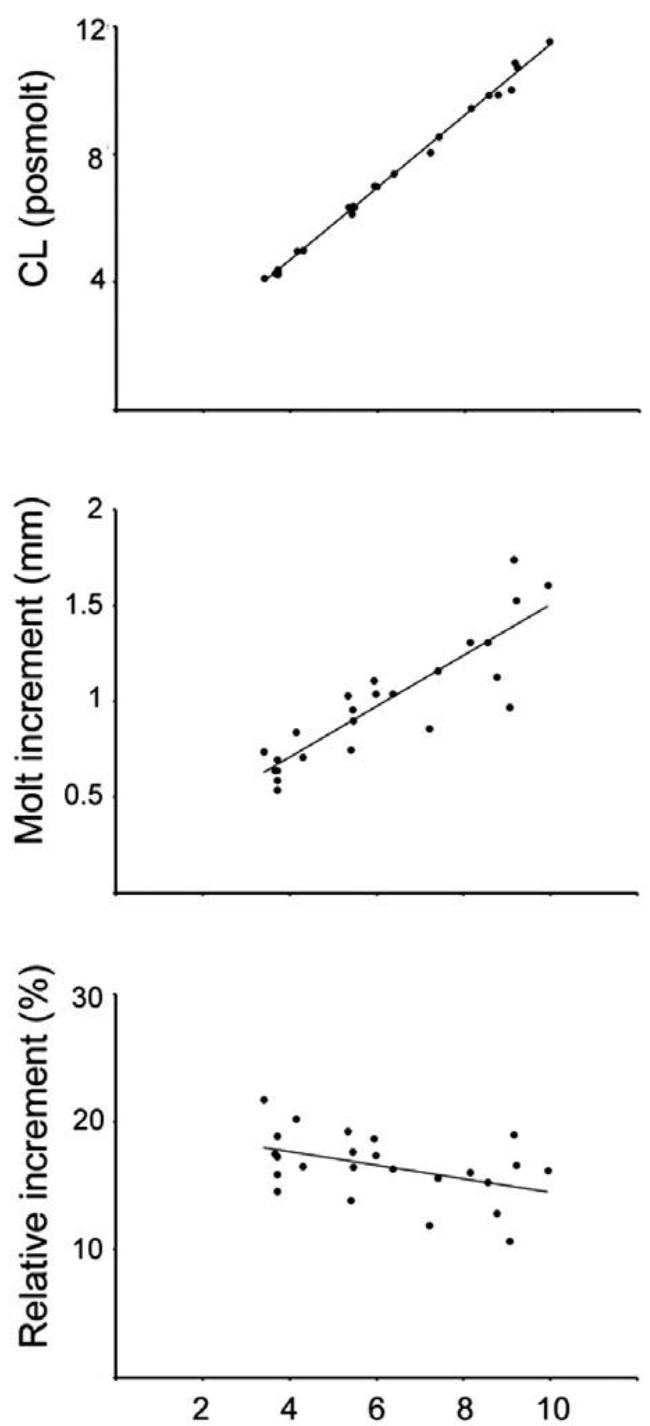

Females
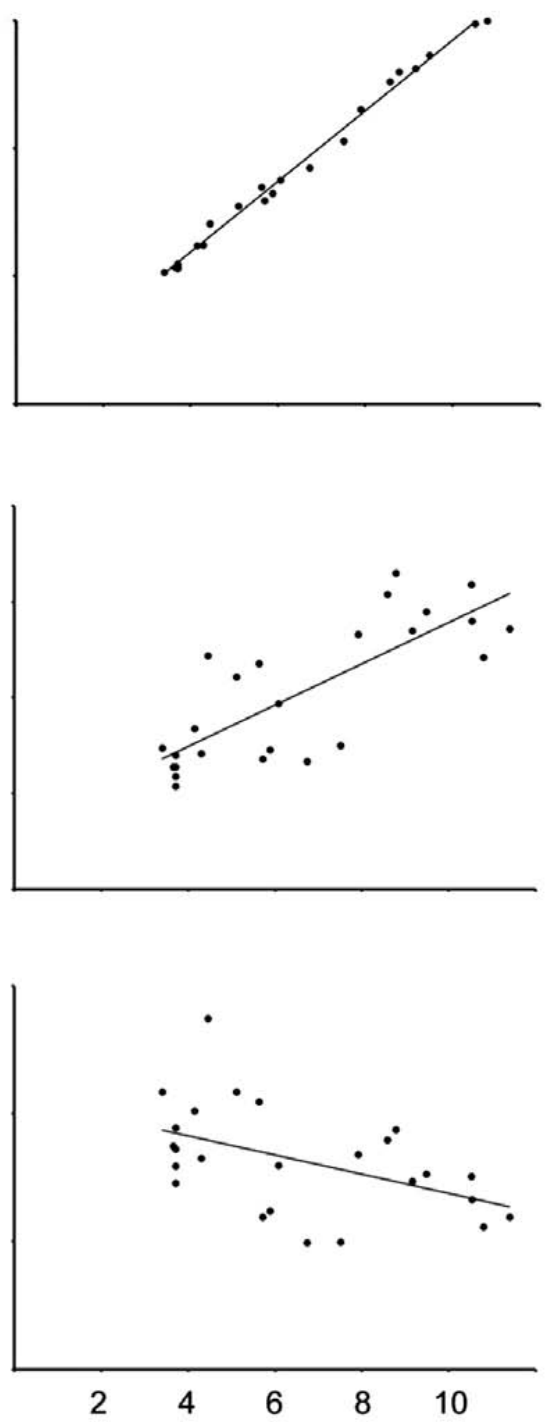

\section{$\mathrm{CL}$ (premolt)}

Fig. 3. - Growth indicators in young of the year of Munida gregaria in San Jorge Gulf. A, $\mathrm{CL}_{\mathrm{pre}}-\mathrm{CL}_{\mathrm{pos}}$ regression; $\mathrm{B}, \mathrm{CL}_{\mathrm{pre}}-$ moult increment (MI) regression; $\mathrm{C}, \mathrm{CL}_{\mathrm{pre}}$ - relative increment (RI) regression.

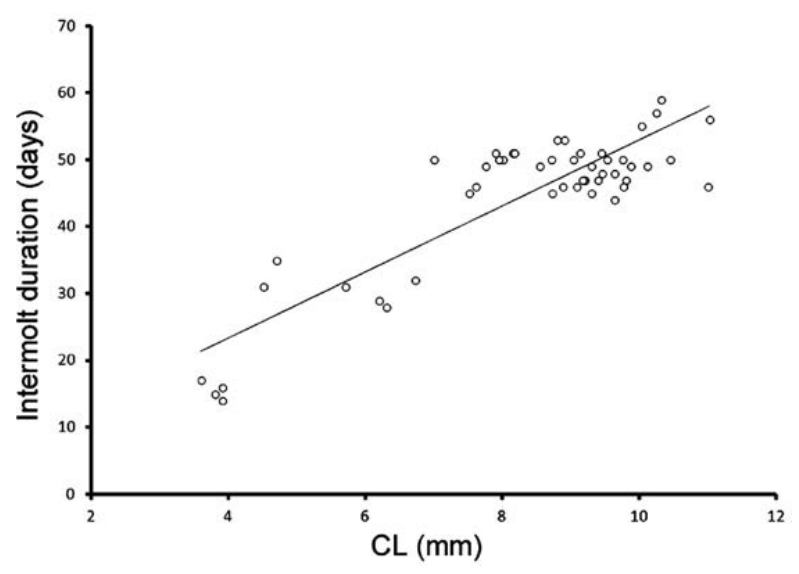

Fig. 4. - Intermoult duration in young of the year of Munida gregaria in laboratory cultures.

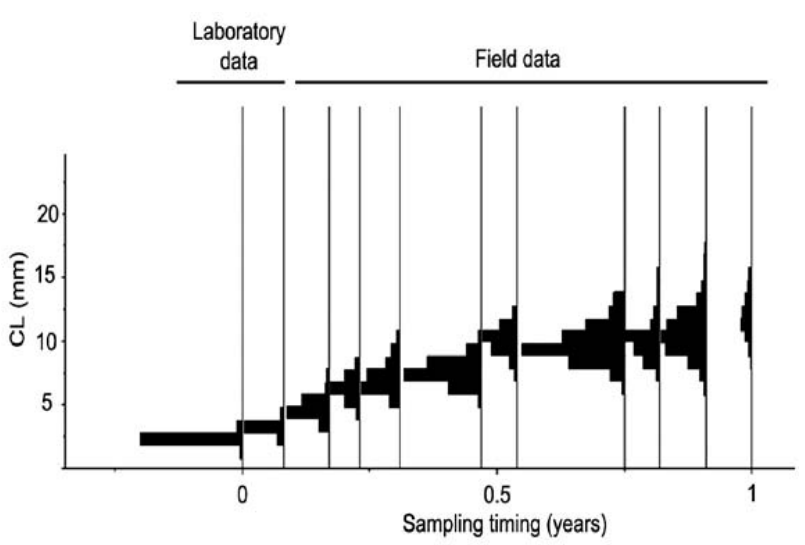

Fig. 5. - Size (CL) frequency distribution of young of the year of Munida gregaria in San Jorge Gulf. 
Table 2. - Size class of young of the year of Munida gregaria in San Jorge Gulf. Mean size (CL), standard deviation (SD) and time (years) after settlement are shown. In size classes I-IV sexual differentiation was not made.

\begin{tabular}{|c|c|c|c|c|c|c|}
\hline \multirow[b]{2}{*}{$\mathrm{SC}$} & \multicolumn{3}{|c|}{ Males } & \multicolumn{3}{|c|}{ Females } \\
\hline & CL & SD & Time & CL & SD & Time \\
\hline I & 2.45 & 0.17 & 0 & 2.45 & 0.17 & 0 \\
\hline II & 3.45 & 0.48 & 0.05 & 3.45 & 0.48 & 0.05 \\
\hline III & 4.65 & 0.53 & 0.10 & 4.65 & 0.53 & 0.10 \\
\hline IV & 5.82 & 0.71 & 0.19 & 5.82 & 0.71 & 0.19 \\
\hline V & 6.79 & 0.51 & 0.23 & 6.81 & 0.64 & 0.23 \\
\hline VI & 8.40 & 0.68 & 0.31 & 8.01 & 0.72 & 0.31 \\
\hline VII & 9.15 & 0.63 & 0.49 & 9.58 & 0.6 & 0.49 \\
\hline VIII & 10.64 & 0.75 & 0.68 & 10.64 & 0.78 & 0.68 \\
\hline IX & 12.56 & 0.44 & 1 & 11.90 & 0.74 & 1 \\
\hline
\end{tabular}

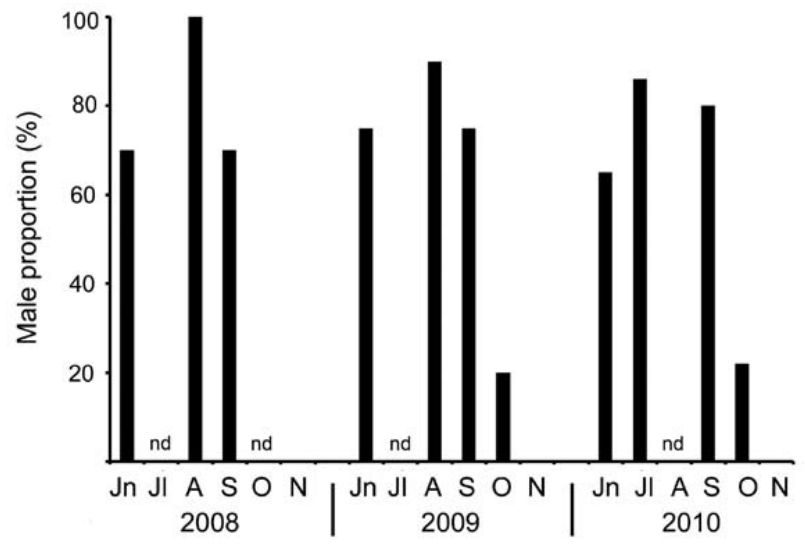

Fig. 6. - Proportion of males that reached gonadal maturity in field samples of young of the year (males) of Munida gregaria in San Jorge Gulf.

At the beginning of the reproductive period (early June), females 0+ showed no mature gonads. In 2010, a low fraction of females $0+$ showed mature gonads. However, samples were carried out at the end of June. The percentage of females $0+$ with mature gonads increased throughout the reproductive season until August, and then the fraction of females with vitellogenic oocytes decreased. Ovigerous females 0+ appeared in August in 2008 and 2009 (no data of July), while in 2010 ovigerous females appeared in July. However, only $\approx 50 \%$ of females $0+$ carried eggs (Fig. 8). In early June, females $0+$ showed oocytes in previtellogenesis. These oocytes were always present from June to October. Females with vitellogenic oocytes were observed in AugustSeptember in all years. In October, when the mating period finished, only females with previtellogenic oocytes were observed. Oocyte size and development were similar in the field and laboratory cultures (Fig. 9). Females in the laboratory experiments moulted in the same periods as males. In AugustSeptember, when vitellogenic oocytes were found, a high proportion of intermoult females were recorded (Fig. 7b). In the moult of June, immature females had moult increments $29 \%$ higher than females that later showed mature gonads (Table 3 ). The moult increments of this experiment were not used in growth analysis due to the long culture time. However, the moult increment was used to evaluate the effects of growth increment in future gonad development.

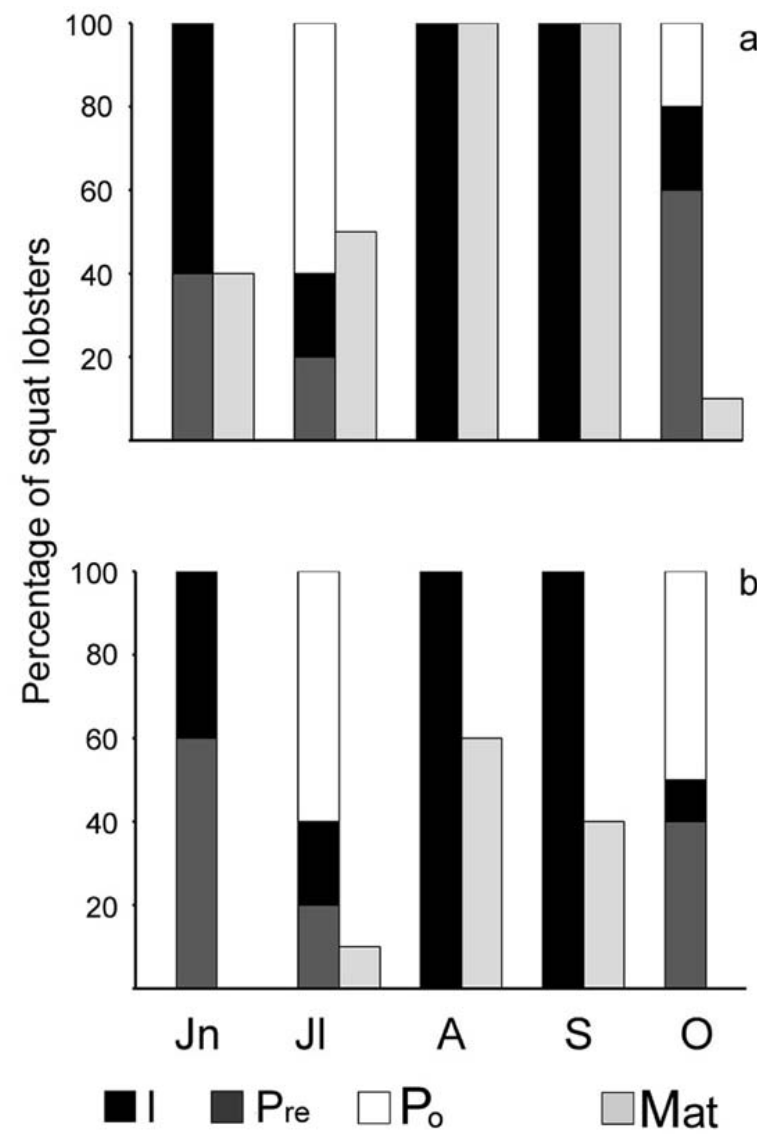

Fig. 7. - moult stages and sexual maturity proportions for males (a) and females (b) of young of the year of Munida gregaria in laboratory experiments. Pre, premoult; I, intermoult; Po, postmoult; Mat, maturity.

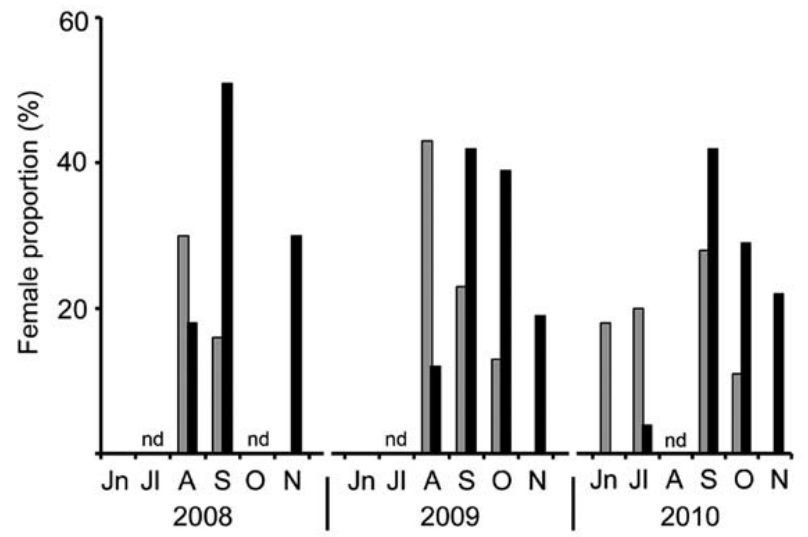

Fig. 8. - Sexual maturity in field samples of young of the year (females) of Munida gregaria in San Jorge Gulf. Grey bars show proportion of females that reached gonadal maturity. Black bars represent proportion of ovigerous females.

Intermoult duration in this experiment was longer than the moult increment experiment, which was performed in a non-reproductive period.

\section{Fecundity and $R O$}

The size of ovigerous females $0+$ ranged between 8.96 and $12.87 \mathrm{~mm}$ CL, while fecundity varied between 


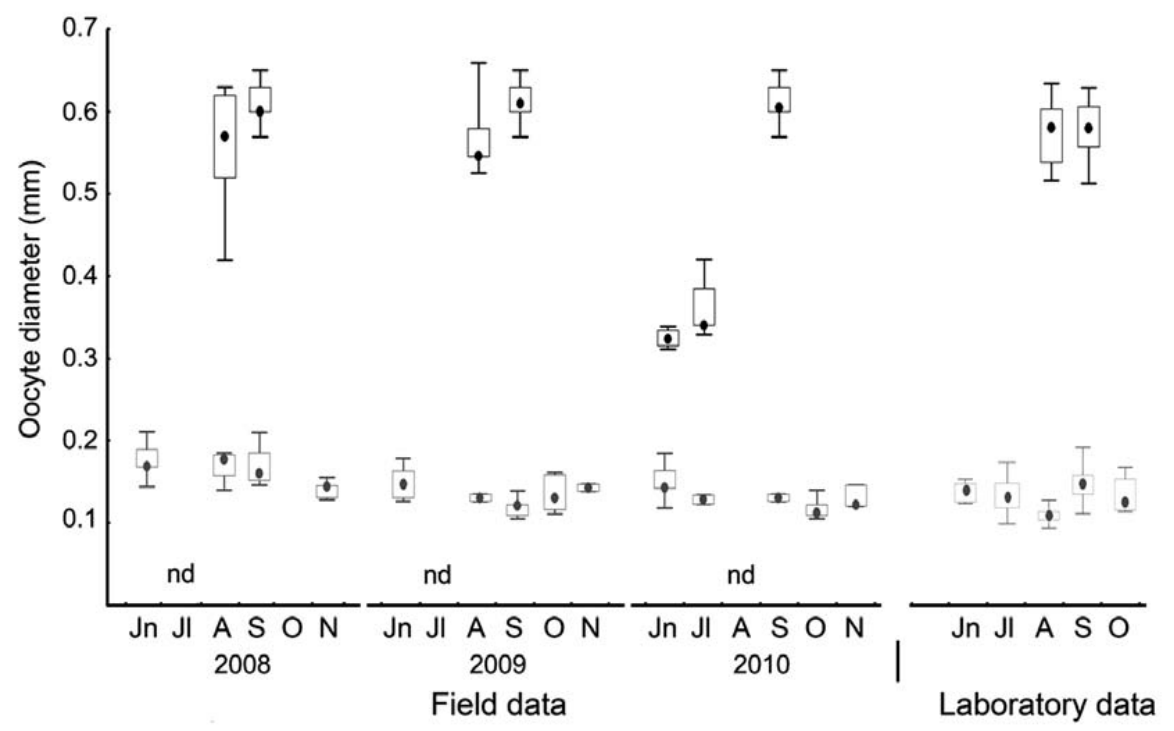

Fig. 9. - Oocyte size (mm) of young of the year of Munida gregaria. Grey box plots represent previtellogenic oocytes, while black box plots represent vitellogenic oocytes. Box plots show the median and inter-quartile range, with whiskers representing the maximum and minimum values.
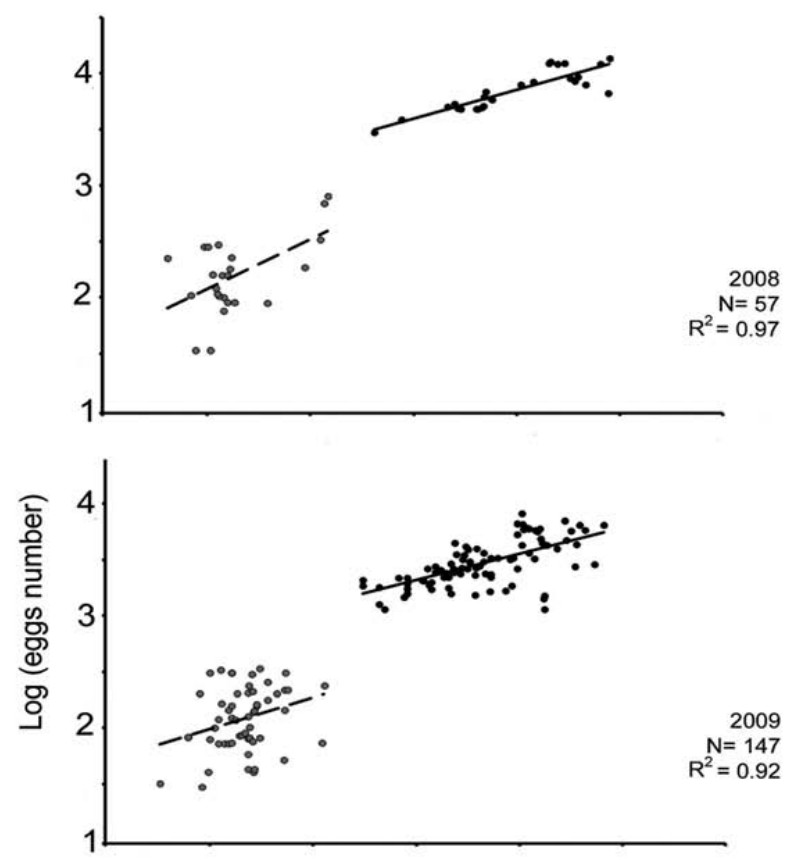

Table 3. - Analysis of covariance to compare moult increments (MI) between females that showed no mature gonads (NMF) and females that later showed mature gonads (MF). MI, adjusted mean of RI; N, number of individuals; F, statistic F; df, degrees of freedom; $\mathrm{P}$, probability; Significance level $(\mathrm{P}<0.05)$

\begin{tabular}{lccccc}
\hline & MI & N & F & df & P \\
\hline MF & 0.98 & 10 & 6.99 & 1,25 & 0.01 \\
NMF & 1.29 & 17 & & & \\
\hline
\end{tabular}

Table 4. - Factorial analysis of variance to evaluate differences in reproductive output between young of the year and older females. Differences between years and age-years interaction were also evaluated. SS, sum of squares; df, degrees of freedom; MS mean square; F, F ratio; P, probability values associated with F; Significance level $(\mathrm{P}<0.05)$.

\begin{tabular}{lccccc}
\hline & SS & df & MS & F & P \\
\hline Age (A) & 602.7 & 1 & 602.7 & 47.57 & 0.00 \\
Year (Y) & 15.9 & 2 & 7.95 & 0.63 & 0.53 \\
A x Y & 20.6 & 2 & 10.3 & 0.81 & 0.44 \\
\hline
\end{tabular}

$30(\mathrm{CL}=9.83 \mathrm{~mm})$ and $339 \mathrm{eggs}(\mathrm{CL}=11.18 \mathrm{~mm})$. The fecundity-size relationship of females $0+$ was significantly different than the fecundity of larger-size cohort (Fig. 10). Significant differences were found in RO between females $0+(6.03 \pm 2.21)$ and older females (11.26 \pm 4.38$)$ (Table 4).

\section{DISCUSSION}

In marine invertebrates, growth rate, size and age at maturity, and fecundity are important life-history traits (Kozlowski 1991, Ramírez Llodra 2002). These traits are related to energy allocation strategies and are the basis of the differences between different life history and population dynamics (Heino and Kaitala 1999, Ramírez Llodra 2002). The early life history of Munida gregaria in San Jorge Gulf is different to that of the more southern populations, such as those of the Strait of Magellan (Rodríguez and Bahamonde 1986) and the Beagle Channel (Tapella 2002). These differences are mainly due to the fact that the young of the year (grey) and older females (black) of Munida gregaria in the San Jorge Gulf. $\mathrm{R}^{2}$, determination coefficient of piecewise regression. 
of the year in San Jorge Gulf could invest energy in reproduction.

Several environmental factors have significant influence on the growth of crustacean species. Among these, temperature is probably the most important and is widely studied in marine invertebrates. An increase in temperature has a positive effect on the growth rate because it reduces the intermoult duration. However, the effect of temperature on moult increment is more variable (see Hartnoll 2001 for review). On this basis, latitudinal variations in intermoult duration and moult increment can be expected in species with a wide latitudinal distribution. In consequence, the young of the year of M. gregaria of the San Jorge Gulf showed slightly shorter intermoult periods than those of the Beagle Channel (Tapella 2002), while moult increments were higher in the San Jorge Gulf. The fast growth of squat lobsters in the San Jorge Gulf determines that they can reach sexual maturity in their first year after settlement. Conversely, in southern populations with slower growth, the species reaches sexual maturity in the second year of postlarval life (Rayner 1935, Rodríguez and Bahamonde 1986, Tapella 2002).

In larger species of squat lobsters, males appear to become sexually mature at smaller sizes than females (Thiel and Lovrich 2012). Size at maturity of M. gregaria is lower in males than in females in both the San Jorge Gulf and the Beagle Channel (Tapella et al. 2002, Vinuesa 2007). Field and experimental data showed that the main fraction of $M$. gregaria males $0+$ in San Jorge Gulf spend energy in gonadal development. However, future studies should be carried out to determine whether males really mate. In this respect, PérezBarros et al. (2011) suggest that the mating strategy in $M$. gregaria is pure search and that single broods could result from several short matings. This strategy could increase the probability of mating success in small males. In females, the proportion of individuals with mature gonads was more variable, but the occurrence of ovigerous females confirmed that they had mated in the first year of life.

Sexual maturity implies a change in the allocation of resources for growth and reproduction. In mature females of crustacean species, reproduction is a major drain upon the available resources. Reproduction investment can affect growth due to a reduction of resource availability to grow (Hartnoll 1985, 2001). In Beagle Channel, moult increments in mature individuals of $M$. gregaria were lower in autumn than in spring. These low increments are related to gonadal development, which squat lobsters show in autumn (Tapella 2002). In San Jorge Gulf, young of the year moulted at the beginning (June) and after the mating period (September-October). In June, moult increments of females that later developed their gonads (vitellogenic oocytes) were lower than those of females that did not reach maturity. However, although no experimental evidence of the effect of reproduction investment on the moult after the breeding period was observed, a negative effect on growth can be expected. In the moult of October, the females that showed vitellogenic oocytes but had not mated (the ovary was reabsorbed) showed moult increments similar to those of females that had not developed oocytes. In field samples, the higher standard deviation of the female cohort after the breeding period suggests a variable growth investment. However, obtaining more information regarding this point is difficult because post-ovigerous squat lobsters cannot be recognized and thus moult experiments cannot be carried out. After hatching, funicles and empty egg cases were not retained. Nevertheless, it is logical to think that if the energy contained in the oocytes is used for reproduction, it will not be available for the next moult.

In crustacean species, the allocation of resources to growth decreases throughout their lives, whereas the fraction of energy allocated to reproduction and maintenance increases (Hartnoll 1985). Primiparous females of snow crabs Chionoecetes bairdi have lower fecundity than multiparous females, possibly due to a higher growth investment in the months before egg extrusion (Somerton and Meyers 1983). Similar results have been reported in Stenorhynchus seticornis (Okamori and Cobo 2003). In the present work, fecundity and $\mathrm{RO}$ of females $0+$ was significantly lower than that of older females. Older individuals moult at the end of summer and develop their ovaries until June, when mating occurs. Young of the year showed moult activity in June. This is why no ovigerous females $0+$ were observed at the beginning of the breeding period. Moult proximity could explain a low reproduction investment of females $0+$, because the energetic cost of this moult reduces energy availability for egg production.

The growth patterns exhibited by the young of the year of Munida gregaria in the San Jorge Gulf determine different strategies in allocation of resources among intracohort females. Our results suggest that females at the end of the first year after the settlement may follow one of two strategies: early maturity with low fecundity or delayed maturity with larger fecundity in the future.

\section{ACKNOWLEDGEMENTS}

We thank the Prefectura Naval Argentina and Servisub SA for their assistance in samplings. This work was partially funded by the Universidad Nacional de la Patagonia San Juan Bosco and the Agencia Nacional de Promoción Científica y Tecnológica (PICTO GSJ 36972), Argentina.

\section{REFERENCES}

Dellatorre F., González-Pisani X. 2010. Embryonic development and fecundity of the squat lobster Munida gregaria (Decapoda: Galatheidae) in northern Patagonia. J. Mar. Biol. Ass. UK 88: 975-981.

Espinoza-Fuenzalida N., Acuña E., Hinojosa I., et al. 2012. Reproductive Biology of two species of Squat Lobsters - Female Receptivity and Interbrood Intervals. J. Crust. Biol. 32: 565-574. http://dx.doi.org/10.1163/193724012X626601

Gayanilo F., Sparre P., Pauly D. 2005. FAO-ICLARM Stock Assessment Tools II (FiSAT II). Revised version. FAO Computerized Information Series 8

Gramitto M., Froglia C. 1998. Notes on the biology and growth of Munida intermedia (Anomura: Galatheidae) in the western Pomo pit (Adriatic Sea). J. Nat. Hist. 32: 1553-1566. 
http://dx.doi.org/10.1080/00222939800771091

Hartnoll R. 1985. Growth, sexual maturity and reproductive output. In: Wenner A.M. (ed.), Crustacean Issues 3. Factors in adult growth. Balkema, pp. 101-128.

Hartnoll R. 2001. Growth in Crustacea - twenty years on. Hydrobiologia 449: 111-122. http://dx.doi.org/10.1023/A:1017597104367

Heino M., Kaitala V. 1999. Evolution of resource allocation between growth and reproduction in animals with indeterminate growth. J. Evol. Biol. 12: 423-429. http://dx.doi.org/10.1046/j.1420-9101.1999.00044.x

Hines A.H. 1982. Allometric constraints and variables of reproductive effort in brachyuran crabs. Mar. Biol. 69: 309-320. http://dx.doi.org/10.1007/BF00397496

Kozlowski J. 1991. Optimall energy allocation models - an alternative to the concepts of reproductive effort and cost of reproduction. Acta Ecol. 12: 11-33.

Kurata H. 1962 Studies on the age and growth of Crustacea. Bul. Hokkaido Reg. Fish. Res. Lab. 24: 1-115.

Okamori C., Cobo J. 2003. Fecundity of arrow crab Stenorhynchus seticornis in the southern Brazilian coast. J. Mar. Biol. Ass. UK 83: 979-980. http://dx.doi.org/10.1017/S0025315403008178h

Palma E., Matano R., Piola A. 2008. A numerical study of the Southwestern Atlantic Shelf circulation: Stratified ocean response to local and offshore forcing. J. Geophys. Res. 113: C11010. http://dx.doi.org/10.1029/2007JC004720

Pérez-Barros P., Calcagno J., Lovrich G.A. 2011. Absence of a prezygotic behavioural barrier to gene flow between the two sympatric morphs of the squat lobster Munida gregaria (Fabricius, 1793) (Decapoda: Anomura: Galatheidae). Helgoland Mar. Res. 65: 513-523. http://dx.doi.org/10.1007/s10152-010-0240-1

Petrić M., Ferri J., Mladineo L. 2010. Growth and reproduction of Munida rutllanti (Decapoda: Anomura: Galatheidae) and impact of parasitism by Pleurocrypta sp. (Isopoda: Bopyridae) in the Adriatic Sea. J. Mar. Biol. Ass. UK 90: 1395-1404. http://dx.doi.org/10.1017/S0025315409991615

Ramírez Llodra E. 2002. Fecundity and life-history strategies in marine invertebrates. Adv. Mar. Biol. 43: 88-162. http://dx.doi.org/10.1016/s0065-2881(02)43004-0

Rayner G. 1935. The Falkland species of the crustacean genus $\mathrm{Mu}$ nida. Discovery Report, 10: 211-245.

Roa R., Bahamonde R. 1993. Growth and expansion of an exploited population of squat lobster (Pleuroncodes monodon) after 3 years without harvesting. Fish. Res. 18: 305-319. http://dx doi org/10.1016/0165-7836(93)90159-5

Rodríguez L., Bahamonde R. 1986. Contribución al conocimiento de Munida subrugosa (White 1847) en la XII Región, Chile. In: Arana P. (ed), La Pesca en Chile. Universidad Católica de Valparaíso, pp. 283-296.

Stearns S.C. 1992. The Evolution of Life Histories. Oxford University Press, Oxford, 262 pp.

Somerton D., Meyers W. 1983. Fecundity differences between primiparous and multiparous female Alaskan tanner crab (Chionoecetes bairdi). J. Crust. Biol. 3: 183-186. http://dx.doi.org/10.2307/1548254

Tapella F. 2002. Reproducción, crecimiento, distribución y abundancia de la langostilla Munida subrugosa (Anomura: Galatheidae) del canal Beagle, Tierra del Fuego, Argentina. PhD thesis, Universidad Nacional de Córdoba, Córdoba. 147 pp.

Tapella F., Lovrich G.A., Romero M.C., et al. 2002. Reproductive biology of the crab Munida subrugosa (Decapoda: Anomura: Galatheidae) in the Beagle Channel, Argentina. J. Mar. Biol. Ass. UK 82: 589-595. http://dx.doi.org/10.1017/S0025315402005921

Thiel M., Lovrich G. 2012. Agonistic behaviour and reproduction biology of squat lobster. In: Poore GCB, Ahyong S.T., Taylor J. (eds). The biology of squat lobsters. CSIRO Publishing: Melbourne and CRC Press, Boca Ratón, pp. 223-248.

Thiel M., Espinoza-Fuenzalida N., Acuña E., et al. 2012. Annual brood number and breeding periodicity of squat lobsters (Decapoda: Anomura: Galatheidae) from the continental shelf of the SE Pacific-Implications for fisheries management. Fish. Res. 129-130: 28-37. http://dx.doi.org/10.1016/j.fishres.2012.06.004

Vinuesa J.H. 2007. Reproduction of the squat lobster Munida gregaria (Decapoda: Galatheidae) in San Jorge Gulf, south-west Atlantic Ocean. J. Crust. Biol. 27: 437-444. http://dx.doi.org/10.1651/S-2787.1

Vinuesa J., Varisco M., Escriche F. 2011. Settlement and recruitment of the crab Halicarcinus planatus (Crustacea: Decapoda: Hymenosomatidae) in Golfo San Jorge, Argentina. J. Mar. Biol. Ass. UK 91: 681-695. http://dx.doi.org/10.1017/S0025315410001864

Wolff M., Aroca T. 1995. Population dynamics and fishery of the Chilean squat lobster Cervimunida johni Porter (Decapoda: Galatheidae) off the coast of Coquimbo, northern Chile. Rev. Biol. Mar. 30: 57-70. 